\title{
Factors Associated with Burnout Among Physicians: An Evaluation During a Period of COVID-19 Pandemic
}

\author{
Sait Revda Dinibutun (D) \\ HRM Department, American University \\ of the Middle East, Kuwait City, Kuwait
}

This article was published in the following Dove Press journal: Journal of Healthcare Leadership

Purpose: The aim of the study is to evaluate the prevalence and extent of burnout among physicians and investigate the factors related with burnout and the influence of the fight against coronavirus (COVID-19) on the burnout syndrome.

Methods: A cross-sectional survey design was adopted and conducted on 200 actively working physicians in Izmir/Turkey. Personal Information Form and Maslach Burnout Inventory were used in the survey.

Results: The findings showed that the emotional exhaustion level of the physicians was medium, the levels of depersonalization and personal accomplishment were low, and the level of total burnout was low. It was observed that the burnout levels of males and females, and married and single physicians were similar. The emotional exhaustion level of 18-23year-old physicians was lower than the rest of the physicians. Physicians' level of satisfaction with their income is not effective on burnout. The burnout level of physicians who did not choose their profession willingly was determined to be higher than the burnout level of the physicians who chose their profession willingly. One important finding showed that the burnout level of physicians who actively involved in the fight against COVID-19 was lower than the burnout level of the physicians who did not actively involve in the fight against COVID-19.

Conclusion: Although the impact of some demographic variables, such as gender, marital status and satisfaction of income on burnout, was similar among the groups, total burnout level was lower in physicians who actively fought with the virus. This result may suggest that those physicians who were actively involved in the fight against COVID-19 had a high sense of meaningfulness of work which will result in high satisfaction with the work itself and, thus, creating less burnout. Also, they had a stronger feeling of personal accomplishment as they faced the immediate outcomes of their care for people infected by COVID-19. Keywords: burnout, healthcare professionals, demographics, COVID-19, pandemic

\section{Introduction}

The COVID-19 epidemic, which the World Health Organization (WHO) has accepted as a "pandemic", is a serious health problem that humanity has faced with. While countries continue their struggle with the epidemic, all healthcare workers have been involved in this difficult struggle regardless of their interests. During this process, physicians often provided the necessary care for suspected or confirmed COVID-19 patients under difficult conditions. They even risked being infected by the virus to protect larger society. Physicians are known to be facing
Correspondence: Sait Revda Dinibutun American University of the Middle East, Block 6, Building I, Egaila, Kuwait City, Kuwait

Tel +96522251400

Fax +96522251425

Email sait.revda@aum.edu.kw
Journal of Healthcare Leadership 2020:12 85-94 
a multitude of challenges at all stages of the pandemic. Several studies have shown that physicians experience depression and anxiety as a result of the coronavirus pandemic, ${ }^{1-3}$ which may trigger burnout. Burnout is recognized as a severe problem among healthcare employees. $^{4,5}$

Burnout is described as a psychological syndrome that is characterized as a negative emotional reaction to one's job as a consequence of extended exposure to a stressful work environment. ${ }^{6-8}$ According to this definition, employees who work in stressful professions are more likely to suffer from burnout. In addition, burnout has been observed in individuals who have high ideals and many interactions with other people. ${ }^{9}$ Healthcare has been listed among the high-stress professions with the need for intensely personal interactions with people, especially patients and other healthcare providers who also suffer from high levels of stress, which creates a higher level of burnout. ${ }^{10,11}$

Physicians, as members of healthcare sector, are also exposed to burnout. Their relationships with a large number of patients, staff and administrators make them leading candidates for burnout. ${ }^{12}$ Regularly, they also deal with many issues, including high expectations, lack of time and social support at work, being responsible for the health and wellbeing of others, patients' aggressive behaviors and complaints, and coping with death and injury. ${ }^{13}$ Physicians who encounter the issues above are more likely to have burnout; those with higher levels of burnout can display their intention towards turnover as well as poor job performance. $^{4,12-15}$

Physician burnout has received increased attention in recent years. ${ }^{16-19}$ Studies have found that burnout rates are higher amongst physicians than individuals in other careers. ${ }^{4,5}$ Physician burnout is important because it is associated with negative consequences on patient care, ${ }^{20-23}$ the physician workforce and healthcare system costs, ${ }^{24,25}$ and physicians' own care and safety. ${ }^{26,27}$ Thus, burnout is a losing situation within physicians as well as the healthcare sector as a whole.

Level of burnout is likely to increase during the COVID-19 pandemic, where physicians are facing a high workload in providing health services. Burnout among physicians has been found to be associated with a wide range of occupational stressors, ${ }^{4,12,13,15,16}$ which are likely to increase during the COVID-19 pandemic. Many of the physicians are withdrawn or suggested self-isolation after working on COVID-19 cases. The fear of being infected and disrupted social support during isolation are critical factors that may influence burnout. ${ }^{28}$ Moreover, lack of personal protective equipment and other preventive measures are found to be associated with burnout and other mental health problems among front-line healthcare providers. $^{29}$

In this study, it is aimed to evaluate the prevalence and extent of burnout among physicians and investigate the factors related with burnout and the influence of the fight against COVID-19 on the burnout syndrome. In this regard, 200 actively working physicians at a public hospital in Izmir/Turkey, who volunteered to participate regardless of their specialty, are involved in the study.

\section{Burnout}

Freudenberger ${ }^{30}$ first described the concept of burnout in 1974 as "a state of exhaustion that results from failure, attrition, loss of energy and power, or unfulfilled wishes on human internal resources." Many researchers have conducted investigations into burnout in different business areas over the last 20 years. In Maslach and Jackson's ${ }^{31}$ most widely accepted conceptualization, burnout is recognized as a three-dimensional syndrome. These three dimensions are emotional exhaustion, depersonalization and personal accomplishment.

Emotional exhaustion is the feeling in the employees of being tired and emotionally worn down. In other words, it is the feeling of being overloaded on the job. It occurs in the form of a lack of energy and the feeling that an individual's emotional resources are gone. Depersonalization is understood as cold, indifferent, rigid, or even inhuman attitudes expressed towards other people while at work. A person behaves in a humiliating and rude manner, ignoring the requests and demands from others. Personal accomplishment is the competency and inner feelings of accomplishment. Personal incompetence means that one considers him/ herself as inadequate and unsuccessful in his/her job. At this stage, the person is personally full of feelings of failure. According to Maslach and Jackson, ${ }^{6}$ each of these dimensions is independent of the other and could arise at any time.

Healthcare professionals are often at high risk of stress, and burnout has been a major concern in the area of occupational health. ${ }^{32}$ Healthcare professionals face extensive stress in their job because they have extended working hours, a wide range of tasks and complex relationships with patients, their families and other colleagues. ${ }^{7}$ In order 
to prevent and reduce burnout, understanding its determinants is very important. ${ }^{33}$

As a consequence of burnout, individuals become distant from the business and family environment, and they experience incompatibilities in interpersonal relationships. Undergoing health problems and having to deal with psychological problems are among the consequences of burnout. Burnout, which has negative effects on both business and social life, is regarded as a phenomenon that needs to be tackled at an individual and organizational level.

\section{Research Methodology}

\section{Aim and Importance of the Study}

The aim of this research is to determine the burnout levels of physicians along with how sociodemographic factors affect the intensity of burnout. Examining the burnout levels of physicians according to sociodemographic characteristics makes the study more significant due to the importance of the health sector. Also, it is aimed to understand the impact of the fight against coronavirus (COVID19) on the burnout levels of the physicians during a period of COVID-19 pandemic.

Determining the burnout levels of employees in the sector is of great importance for providing quality health services and protecting the wellbeing of employees. Burnout is described as a syndrome that threatens many dynamics in business life, which establishes the importance of the research. It is also important to obtain data from a different region that has not been examined previously during a pandemic period. By doing so, it is regarded to be important in terms of better analysis of the subject by adding a new source to the limited researches in this field.

\section{Research Design}

A cross-sectional survey design was adopted. The research data were collected with a 2-part measuring tool. The first part of the measurement tool consists of the Personal Information Form, in which the demographic characteristics of the participants are questioned whereas the second part consists of Maslach Burnout Inventory developed by Maslach and Jackson ${ }^{34}$ to measure burnout levels.

\section{Population and Sample of the Research}

The population of the research consists of all physicians at a public hospital in Izmir/Turkey. In this cross-sectional study, after taking the time, the financial constraints and the current pandemic situation into account in reaching the population, it was aimed to reach the physicians by convenience sampling and 200 physicians, who volunteered to participate in the research and fill out the questionnaire, were involved in the study.

\section{Instruments}

\section{Personal Information}

Demographic details of gender, age, marital status and satisfaction from income were elicited using a selfadministered questionnaire. The participants were also asked whether they were actively involved in the fight against the virus.

\section{Burnout Inventory}

Maslach Burnout Inventory (MBI) was developed by Maslach and Jackson. ${ }^{34}$ The Turkish adapted version of MBI by Ergin ${ }^{35}$ is utilized to determine the burnout levels in this study as a data collection tool. MBI is a Likert-type scale consisting of 22 items and was scored as $1=$ never, $2=$ very rare, $3=$ sometimes, $4=$ often and $5=$ always. In the evaluations made about the values in this section, the burnout levels are considered as very low between the values of 1.00-1.80; low between the values of 1.812.60; medium between the values of 2.61-3.40; high between the values of 3.41-4.20; and very high between the values of 4.21-5.00. Items 1, 2, 3, 6, 8, 13, 14, 16, 20 of this inventory are included in the sub-dimension of emotional exhaustion; items 5, 10, 11, 15, 22 are included in the sub-dimension of depersonalization; and items 4, 7, $9,12,17,18,19,21$ are included in the sub-dimension of personal accomplishment. Cronbach's alpha coefficients were calculated to determine the reliability levels of the scales used in the research.

\section{Data Analysis}

All statistics were performed with SPSS for Windows 22.0 software package program. Reliability analyses were conducted on the scales. Percentage, frequency, median and standard deviation statistics were used in determining descriptive characteristics. Shapiro-Wilk test was used to test the compatibility for normal distribution and to determine whether the variables are suitable for normal distribution or not.

According to the results, it was determined that the variables did not show normal distribution since emotional exhaustion, depersonalization, personal accomplishment and burnout total scores are $\mathrm{p}<0.05$. When there is no normal 
distribution, Mann Whitney- $U$ Test will be used for variables with two groups and Kruskal-Wallis- $H$ Test will be used for variables with more than two groups. In addition, the error rate is determined as $(\dot{\alpha}=0.05)$ in all tests and the difference between the groups will be considered statistically significant when $p<0.05$. Comments will be made in light of the tables constructed by analyzing the data.

\section{Ethics Statement}

All participants received oral information about the purpose of the study. Informed consent was obtained prior to data collection and study participants were informed that their participation was voluntary and they could withdraw at any time. The data were handled confidentially. No personal identifiers were collected. The study was approved by the Institutional Review Board (IRB) of Izmir County Health Department before data collection and adhered to the tenets of the Declaration of Helsinki for research involving human subjects. The study also complied with the ethical principles for research within Turkish law (TR-IJ Evaluation Criteria, A-8). The author was affiliated to the current institution in Kuwait at the time of the study.

\section{Results}

The reliability of the burnout scale consisting of 22 items applied to the sample group is found to be 0.815 and highly reliable; therefore, the measurement tool has internal consistency.

According to Table 1, it was determined that the emotional exhaustion level of the physicians was $(3.00 \pm 0.62)$ "medium"; the level of depersonalization was $(2.00 \pm 1.01)$ "low"; the level of personal accomplishment was (2.00 $\pm 0.57)$ "low"; and the level of total burnout was $(2.50$ \pm 0.43 ) "low".

When the demographic characteristics of the physicians participating in the research are examined, it can be seen that $59 \%$ are women and $41 \%$ are men; $68.5 \%$ are married, $31.5 \%$ are single; $3 \%$ are $18-23$ years old, $16 . \%$

Table I Emotional Exhaustion, Depersonalization, Personal Accomplishment and Total Burnout Level

\begin{tabular}{|l|l|l|}
\hline & Median & SD \\
\hline Emotional Exhaustion & 3.00 & 0.62 \\
Depersonalization & 2.00 & 1.01 \\
Personal Accomplishment & 2.00 & 0.57 \\
Burnout & 2.50 & 0.43 \\
\hline
\end{tabular}

are $24-29$ years old, $22 \%$ are $30-38$ years old, $36 \%$ are $39-47$ years old, $18 \%$ are $48-55$ years old, $4.5 \%$ are 56 years old and above; $1.5 \%$ have $0-1$ year of experience, $15.5 \%$ have $2-3$ years of experience, $21.5 \%$ have $4-6$ years of experience, $24 \%$ have $7-9$ years of experience, $37.5 \%$ have 10 years or more experience as a physician; $69 \%$ of the physicians stated that they were satisfied with their income and $31 \%$ of them were not satisfied with their income; $84.5 \%$ of the physicians stated that they worked as a physician willingly, and $15.5 \%$ of the physicians stated that they did not choose physician profession willingly; $62.5 \%$ of the physicians stated that they were satisfied with their profession, 19\% were not satisfied with their profession and $18.5 \%$ were undecided about whether they were satisfied with their profession or not; $13.5 \%$ of the physicians stated that they wanted to practice a different profession, $63.5 \%$ did not want to practice a different profession and $23 \%$ were undecided about whether they wanted to practice a different profession or not. It has also been observed that $55 \%$ of the physicians were actively involved in the fight against COVID-19 and $45 \%$ were not actively involved in the fight against COVID-19.

In Table 2, according to the results of the Mann Whitney $U$-test conducted to determine whether or not emotional exhaustion, depersonalization, personal accomplishment and burnout differ by gender, it is found that the emotional exhaustion of males and females is similar $(p=0.091, p>0.05)$. There was no significant difference found between the median values of depersonalization $(p=0.173, p>0.05)$, personal accomplishment $(p=0.760$, $\mathrm{p}>0.05)$, and total burnout levels $(\mathrm{p}=0.565, \mathrm{p}>0.05)$. The burnout levels of males and females are similar.

In Table 3, according to the results of the Mann Whitney $U$-test conducted to determine whether or not emotional exhaustion, depersonalization, personal accomplishment and burnout differ depending on the marital status variable, no significant difference was discovered between the median values of emotional exhaustion $(p=0.286, p>0.05)$, depersonalization $(p=0.757, p>0.05)$, and personal accomplishment levels $(\mathrm{p}=0.182, \mathrm{p}>0.05)$. The burnout levels of married and single physicians are similar to each other $(\mathrm{p}=0.263, \mathrm{p}>0.05)$.

According to the results of the Kruskal-Wallis test conducted to determine whether or not emotional exhaustion, depersonalization, personal accomplishment and burnout differ depending on age variable, there was a significant difference between the emotional exhaustion level and the median 
Table 2 Mann Whitney U-Test of Emotional Exhaustion, Depersonalization, Personal Accomplishment and Burnout Scores According to Gender

\begin{tabular}{|l|l|l|l|l|l|l|}
\hline & & $\mathbf{n}$ & Median & SD & $\mathbf{Z}$ & $\mathbf{p}$ \\
\hline Emotional & Female & 118 & 3.00 & 0.75 & -1.69 & 0.091 \\
Exhaustion & Male & 82 & 3,00 & 0,97 & & \\
\hline Depersonalization & Female & 118 & 2.00 & 1.26 & -1.362 & 0.173 \\
& Male & 82 & 2.00 & 1.45 & & \\
\hline Personal & Female & 118 & 2.00 & 0.9 & -0.305 & 0.76 \\
Accomplishment & Male & 82 & 2.00 & 0.67 & & \\
\hline Burnout & Female & 118 & 2.25 & 0.69 & -0.575 & 0.565 \\
& Male & 82 & 2.50 & 0.88 & & \\
\hline
\end{tabular}

Table 3 Mann Whitney U-Test of Emotional Exhaustion, Depersonalization, Personal Accomplishment and Burnout Scores According to Marital Status

\begin{tabular}{|l|l|l|l|l|l|l|}
\hline & & $\mathbf{n}$ & Median & SD & $\mathbf{Z}$ & $\mathbf{p}$ \\
\hline Emotional & $\begin{array}{l}\text { Married } \\
\text { Exhaustion }\end{array}$ & $\begin{array}{l}137 \\
63\end{array}$ & 3.00 & 0.73 & -4.352 & 0.286 \\
\hline Depersonalization & $\begin{array}{l}\text { Married } \\
\text { Single }\end{array}$ & $\begin{array}{l}137 \\
63\end{array}$ & $\begin{array}{l}1.00 \\
2.00\end{array}$ & 1.34 & -0.31 & 0.757 \\
\hline Personal & Married & 137 & 2.00 & 0.67 & -1.335 & 0.182 \\
Accomplishment & Single & 63 & 2.00 & 1.00 & & \\
\hline Burnout & Married & 137 & 2.50 & 0.76 & -1.119 & 0.263 \\
& Single & 63 & 2.00 & 0.82 & & \\
\hline
\end{tabular}

values. The emotional exhaustion levels of 24-29-year-olds, 30-38-year-olds, 39-47-year-olds, 48-55-year-olds and 56 years old and over are higher than the emotional exhaustion level of $18-23$-year-old physicians $(\mathrm{p}<0.05)$. There was also a significant difference between the depersonalization level and the median values. The depersonalization levels of 24 29-year-olds, 48-55-year-olds and 56-year-olds and above are higher than that of 18-23-year-old physicians $(\mathrm{p}=0.001$, $\mathrm{p}<0.05$ ). There was no significant difference found between the median values of total burnout levels $(\mathrm{p}=0.076, \mathrm{p}>0.05$ ).

The results of the Mann Whitney $U$-test conducted to determine whether or not emotional exhaustion, depersonalization, personal accomplishment and burnout differ by the variable of the satisfaction status of income showed no significant difference between the median values of emotional exhaustion $(\mathrm{p}=0.0610, \mathrm{p}>0.05)$, depersonalization $(\mathrm{p}=0.449$, $\mathrm{p}>0.05)$, personal accomplishment $(\mathrm{p}=0.525, \mathrm{p}>0.05)$, and total burnout levels $(p=0.409, p>0.05)$. Burnout values of physicians who are satisfied with their income and those who are not satisfied with their income are similar.
Table 4 Mann Whitney U-Test of Emotional Exhaustion, Depersonalization, Personal Accomplishment and Burnout Scores According to the Enthusiasm to Choose the Profession

\begin{tabular}{|l|l|l|l|l|l|l|}
\hline & & $\mathbf{n}$ & Median & SD & $\mathbf{Z}$ & $\mathbf{p}$ \\
\hline Emotional & Yes & 169 & 3.00 & 0.85 & -0.175 & 0.8610 \\
Exhaustion & No & 31 & 3.00 & 0.83 & & \\
\hline Depersonalization & Yes & 169 & 1.00 & 1.34 & -1.733 & 0.083 \\
& No & 31 & 3.00 & 1.23 & & \\
\hline Personal & Yes & 169 & 2.00 & 0.74 & -2.924 & 0.003 \\
Accomplishment & No & 31 & 2.50 & 1.03 & & \\
\hline Burnout & Yes & 169 & 2.00 & 0.79 & -3.19 & 0.001 \\
& No & 31 & 3.00 & 0.72 & & \\
\hline
\end{tabular}

In Table 4, according to the results of the Mann Whitney $U$-test conducted to determine whether or not emotional exhaustion, depersonalization, personal accomplishment and burnout differ by the variable of enthusiasm to choose the profession, there was no significant difference found between the median values of emotional exhaustion $(\mathrm{p}=0.861, \mathrm{p}>0.05)$ and depersonalization levels $(\mathrm{p}=0.083, \mathrm{p}>0.05)$ of the physicians.

It was determined that the personal accomplishment level of the physicians who chose their profession willingly is significantly higher than the personal accomplishment level of the physicians who did not choose their profession willingly $(\mathrm{p}=0.003, \mathrm{p}<0.05)$. The burnout level of the physicians who did not choose their profession willingly was determined to be significantly higher than the burnout level of the physicians who chose their profession willingly $(\mathrm{p}=0.001, \mathrm{p}<0.05)$.

According to the results in Table 5, there was no significant difference found between the median values

Table 5 Mann Whitney U-Test of Emotional Exhaustion, Depersonalization, Personal Accomplishment and Burnout Scores According to Being Active in the Fight Against the COVID-I 9 Pandemic

\begin{tabular}{|l|l|l|l|l|l|l|}
\hline & & $\mathbf{n}$ & Median & SD & $\mathbf{Z}$ & $\mathbf{p}$ \\
\hline Emotional & Yes & 110 & 2.50 & 0.76 & -0.575 & 0.892 \\
Exhaustion & No & 90 & 2.50 & 0.85 & & \\
\hline Depersonalization & Yes & 110 & 3.00 & 0.65 & -0.31 & 0.090 \\
& No & 90 & 3.00 & 0.68 & & \\
\hline Personal & Yes & 110 & 2.00 & 0.46 & -2.046 & 0.001 \\
Accomplishment & No & 90 & 2.50 & 0.43 & & \\
\hline Burnout & Yes & 110 & 2.00 & 0.50 & -1.325 & 0.036 \\
& No & 90 & 3.00 & 0.55 & & \\
\hline
\end{tabular}


of emotional exhaustion and depersonalization levels of the physicians who were actively involved in the fight against COVID-19 and those were not $(p=0.892, p>0.05$; $\mathrm{p}=0.090, \mathrm{p}>0.05$ ).

A significant difference was found between the median values of the personal accomplishment and the total burnout levels of the physicians who were actively involved in the fight against COVID-19 and those were not ( $\mathrm{p}=0.001$, $\mathrm{p}<0.05 ; \mathrm{p}=0.036, \mathrm{p}<0.05)$. The personal accomplishment level of the physicians who actively fought against the virus is higher than the personal accomplishment level of the physicians who did not actively fight against the virus. Also, the burnout level of the physicians who did not actively fight against the virus was determined to be higher than the burnout level of the physicians who actively fought against the virus.

\section{Discussion}

The aim of this study was to determine the burnout levels of physicians and the factors affecting the burnout level of physicians and contribute to the employees in the sector by developing suggestions in this regard. It is believed that this is one of the pioneer studies focusing on demographic factors along with the comparison of the burnout levels of physicians fighting against COVID-19 pandemic versus those not actively involved.

In this study, it has been determined that the burnout levels of males and females, and married and single physicians were similar. The emotional exhaustion level of 18-23-year-old physicians was lower than the rest of the physicians. Physicians' level of satisfaction with their income is not effective on burnout. The burnout level of physicians who did not choose their profession willingly was determined to be higher than the burnout level of the physicians who chose their profession willingly. An important finding showed that the burnout level of physicians who actively involved in the fight against COVID-19 was lower than the burnout level of the physicians who did not actively involve in the fight against COVID-19.

When similar studies in the literature are examined, it is seen that the results are consistent with the current study. According to Karsavuran, ${ }^{36}$ burnout is an undeniable threat to healthcare professionals. It is noted that the emotional stress factor is among the causes of burnout for healthcare workers. Yildiz, Cicek, and Sanli ${ }^{37}$ conducted a study that showed healthcare professionals are in the top ranks among professions with burnout levels. Researchers have recommendations for reducing burnout by creating flexibility in working conditions. It was expressed that the behaviors of the employees would be improved by this way. In their research, Arık and Turunç ${ }^{38}$ stated that pharmacists, together with nurses, physicians, healthcare assistant professionals and psychologists, are the main healthcare sector workers who experience burnout syndrome.

In the study by Sayıl, Haran, Ölmez, and Özgüven, ${ }^{39}$ burnout appears to be a frequent disorder in professions closely related to people, such as physicians and nurses. The aim of their study was to determine the prevalence of burnout syndrome among physicians and nurses working in the Faculty of Medicine and the factors affecting the burnout level. According to the results of the research, there was a significant difference in the emotional exhaustion subscale between nurses and physicians, whereas there was no significant difference in personal accomplishment and depersonalization subscales. In addition, gender, age and working time were not observed to have a significant effect on the scores obtained from the scales. Ari and $\mathrm{Bal}^{40}$ tried to draw a conceptual framework regarding the concept of burnout based on the previous studies. The study showed that individual and social features, such as gender, age, working hours, personality, values, social support, along with work and organizational features, such as workload, level of control over the job, rewards, sense of belonging to the organization and justice, have a decreasing or increasing effect on burnout.

Helvacı and Turhan's ${ }^{41}$ study described burnout as a persistent chronic sensitivity condition that occurs in working people as a response to stress. The aim of the study was to determine the burnout levels of 130 healthcare professionals and reveal the status of burnout levels in terms of demographic variables and other variables. In the comparisons made in terms of burnout sub-dimensions and demographic factors, it appeared that the effects of occupational variables, such as workload, service time, as well as demographic variables such as gender, age, education, profession and income, were significant.

In the study by Can, Güçlü, Doğan, and Erkaleli, ${ }^{42}$ assistant physicians who received specialized training in the surgical and non-surgical branches were examined in terms of burnout syndrome and the factors that played a role in burnout. A questionnaire was distributed to 855 assistant physicians, examining factors associated to burnout and sociodemographic characteristics. Emotional exhaustion was found high in $75.3 \%$ of the physicians and depersonalization levels were high in $63.5 \%$ of the physicians, despite 
only $11.8 \%$ had a low sense of personal accomplishment in internal branches. Emotional exhaustion was observed in $50 \%$ of the assistant physicians in surgical branches, and, despite the depersonalization levels in $65 \%$ being high, only $8.8 \%$ had a low level of personal accomplishment. The number of those who experienced emotional exhaustion in internal branches was found to be significantly higher than surgical branches. There was no significant difference between the two groups in terms of depersonalization and personal accomplishment. Emotional exhaustion and depersonalization rates were found to be high among physicians operating in internal and surgical branches. These data emphasized the necessary measures to be taken by the clinic and hospital management to diminish the burnout of all assistants.

One of the findings of this study showed that the burnout levels of physicians do not differ significantly by gender. This finding is consistent with the findings of $\mathrm{Wu}$ et $\mathrm{al}^{43}$ and $\mathrm{Pu}_{\mathrm{e}} \mathrm{al}^{44}$ where they find that the prevalence of burnout was similar among women and men. Age and marital status are also determined as variables that do not affect the burnout levels of physicians. These findings are consistent with the findings of Gunasingam, Burns, Edwards, Dinh, and Walton, ${ }^{45}$ where there was no association between burnout and the demographic variables of age and marital status, respectively.

The level of satisfaction with income was thought to be effective on burnout. ${ }^{46}$ However, the level of physicians' satisfaction with their income was not effective on burnout according to the results obtained in this study, which supports the study of Ogundipe, Olagunju, Lasebikan, and Coker. ${ }^{47}$

Another finding of the study showed that the burnout levels of physicians differed according to their enthusiasm to choose their profession. The burnout level of the physicians who did not choose their profession willingly was determined to be higher than the burnout level of the physicians who chose their profession willingly. This result is consistent with the findings of a report by SaglikSen. ${ }^{48}$ The fact that the health sector has a face-to-faceintensive feature results in the necessity to give more importance to this profession and the result shows that this profession needs engaged, passionate people.

In this study, medium level of emotional exhaustion and low levels of depersonalization, personal accomplishment and total burnout among physicians were found. Similar studies achieved different outcomes. Giusti et $\mathrm{al}^{49}$ reported moderate to severe levels of emotional exhaustion and reduced personal accomplishment in more than $60 \%$ of health professionals, and moderate to severe levels of depersonalization in more than $25 \%$ of health professionals. Another study by Azoulay et $\mathrm{al}^{50}$ found a prevalence of burnout in ICU physicians of $52 \%$, which they state as above normal. Study by Barello et $\mathrm{al}^{51}$ indicated that the levels of emotional exhaustion appeared higher than normative values and the percentage of workers with high levels of burnout was significantly higher than the one found in other samples before COVID-19 outbreak. This is a contrary finding to the current study findings.

Finally, in this study, an important finding showed that those participants who actively fought with the virus had a significantly lower level of burnout than others during a period of the COVID-19 crisis. This finding is consistent with the result of the study of $\mathrm{Wu}$ et $\mathrm{al}^{52}$ where they observed a lower level of burnout of the medical professionals on the frontline wards compared to others in normal wards in Wuhan, China. It is also consistent with the result of the study of Dimitriu et $\mathrm{al}^{53}$ where they found that the burnout was significantly more frequent in normal wards (prevalence 86\%) compared to frontline medical residents who showed a prevalence of burnout of only $66 \%$. On the contrary, the study by Kannampallil et $\mathrm{al}^{54}$ found that physician trainees exposed to COVID-19 patients were significantly more stressed and experienced greater burnout. The overall prevalence of burnout in the non-exposed group was lower.

\section{Limitations and Suggestions for Future Research}

There are some limitations in this study. First, the study results were derived from a limited sample. Similar surveys with higher sample sizes may provide different results. Second, the participants in this study were mainly from one city, Izmir. To enhance generalizability, future research might include physicians from other cities in Turkey. Lastly, the research was conducted in April 2020, when COVID-19 had hit its peak in Turkey; the study does not identify the burnout levels of physicians at the beginning of the crisis. Future research may aim at evaluating the burnout levels of physicians when COVID19 is to be considered under control. This would be a follow-up for the current study and provide comparable results.

Further studies incorporating social support in healthcare workers and focusing on some other behavioral 
effects of COVID-19 pandemic, such as work-life balance, turnover intention and job satisfaction, would contribute to the literature. The study was conducted at a public hospital. A comparative analysis could be made in the future by including both public and private hospitals. This would reveal any possible differences between the physicians' burnout levels due to the different structures of the hospitals regarding their organizational culture and climate.

\section{Conclusion}

Although the impact of some demographic variables, such as gender, marital status, and satisfaction of income on burnout, were similar among the groups, total burnout level was lower in physicians who actively fought with the virus. A couple of explanations could be given for this situation. One possible explanation is that, by directly fighting with the virus, physicians may have experienced an intense feeling of "meaningfulness of work" caused by high "job significance"; job significance is the degree to which the job has a substantial impact on the lives of other people, resulting in a high sense of meaningfulness of work that reflects the degree to which work tasks are viewed as something that "counts" in the employees' system of beliefs. ${ }^{55}$ Having a high sense of meaningfulness of work will result in high satisfaction with the work itself and, thus, creating less burnout. ${ }^{34,55,56}$ Another explanation could be the fact that those physicians who were actively fighting against the virus had a stronger feeling of personal accomplishment as they faced the immediate outcomes of their help for people infected by COVID-19.

Interventions that minimize burnout will improve the care of patients and their healthcare providers. Supporting physicians in all aspects is vital to sustaining a healthy workforce during the pandemic. The following suggestions may be taken into consideration in this regard.

Expectations should be clearly communicated and sufficient resources and effective personal protective equipment should be provided, as inadequate personal protective equipment (PPE) and lack of control over procedures are found to be a contributor to burnout. ${ }^{57}$ Providing support from the leadership regarding quarantine directives and guidelines would also help to decrease the possible pressure on the physicians. Physicians' burnout has a direct impact on fatigue, stress, anxiety, depression, poor patient quality care and early retirements. ${ }^{58}$ To maintain personal wellbeing of the physicians, their wellness should be monitored and the concerns regarding the safety of themselves and their families should be addressed. Continuously updating the knowledge regarding COVID-19, as the information evolves rapidly, may reduce the stress levels of the physicians, knowing that they are providing their care with the possible latest information.

Moreover, evidence from the studies confirms that the following suggestions can be effective in addressing physician burnout. ${ }^{10,15,59-61}$ In terms of excessive workload, appropriate distribution of job roles would ease the pressure. Regarding the lack of work support, non-physician staff may support to offload clerical burdens. To overcome the lack of work-home integration, considering home responsibilities in setting schedules for work and meetings, as well as including all required work tasks within expected work hours, would be helpful. Awareness about physician burnout, and stress management training would be also effective solutions. It is hoped that these suggestions would contribute to the wellbeing of the physicians.

\section{Disclosure}

The author reports no conflicts of interest in this work.

\section{References}

1. Chen Q, Liang M, Li Y, et al. Mental health care for medical staff in China during the COVID-19 outbreak. Lancet Psychiatry. 2020;7(4): e15-e16. doi:10.1016/S2215-0366(20)30078-X

2. Koh D. Occupational risks for COVID-19 infection. Occup Med (Chic Ill). 2020;70(1):3. doi:10.1093/occmed/kqaa036

3. Rimmer A. Covid-19: give NHS staff rest spaces and free parking not thank you, says doctor. BMJ. 2020;368:m1171. doi:10.1136/bmj. $\mathrm{m} 1171$

4. Shanafelt TD, Boone S, Tan L, et al. Burnout and satisfaction with work-life balance among US physicians relative to the general US population. Arch Intern Med. 2012;172(18):1377-1385. doi:10.1001/ archinternmed.2012.3199

5. Shanafelt TD, Hasan O, Dyrbye LN, et al. Changes in burnout and satisfaction with work-life balance in physicians and the general US working population between 2011 and 2014. Mayo Clinic Proc. 2015;90(12):1600-1613. doi:10.1016/j.mayocp.2015.08.023

6. Maslach C, Jackson SE. Burnout in organizational settings. Applied Soc Psychol Ann. 1984;5:133-153.

7. Maslach C, Schaufeli WB, Leiter MP. Job burnout. Ann Rev Psychol. 2001;52(1):397-422. doi:10.1146/annurev.psych.52.1.397

8. Marek T, Schaufeli WB, Maslach C Professional Burnout: Recent Developments in Theory and Research. Routledge; 2017; doi:10. 4324/9781315227979

9. Evers W, Tomic W, Brouwers A. Constructive thinking and burnout among secondary school teachers. Soc Psychol Educ. 2005;8 (4):425-439. doi:10.1007/s11218-005-0663-8

10. Ruotsalainen JH, Verbeek JH, Mariné A, Serra C. Preventing occupational stress in healthcare workers. Cochrane Database Sys Rev. 2014; 11 .

11. Krystal JH, McNeil RL. Responding to the hidden pandemic for healthcare workers: stress. Nat Med. 2020;26(5):639. doi:10.1038/ s41591-020-0878-4 
12. Rotenstein LS, Torre M, Ramos MA, et al. Prevalence of burnout among physicians: a systematic review. JAMA. 2018;320 (11):1131-1150. doi:10.1001/jama.2018.12777

13. Ogińska-Bulik N. Occupational stress and its consequences in healthcare professionals: the role of type D personality. Int J Occup Med Environ Health. 2006;19(2):113-122. doi:10.2478/v10001-006-0016-7

14. Romani M, Ashkar K. Burnout among physicians. Libyan J Med. 2014;9(1):1. doi:10.3402/ljm.v9.23556

15. West CP, Dyrbye LN, Shanafelt TD. Physician burnout: contributors, consequences and solutions. J Intern Med. 2018;283(6):516-529. doi:10.1111/joim.12752

16. Dyrbye LN, Thomas MR, Massie FS, et al. Burnout and suicidal ideation among US medical students. Ann Intern Med. 2008;149 (5):334-341. doi:10.7326/0003-4819-149-5-200809020-00008

17. West CP, Shanafelt TD, Kolars JC. Quality of life, burnout, educational debt, and medical knowledge among internal medicine residents. JAMA. 2011;306(9):952-960. doi:10.1001/jama.2011.1247

18. Dyrbye LN, West CP, Satele D, et al. Burnout among US medical students, residents, and early career physicians relative to the general US population. Acad Med. 2014;89(3):443-451. doi:10.1097/ ACM.0000000000000134

19. Dyrbye L, Shanafelt T. A narrative review on burnout experienced by medical students and residents. Med Edu. 2016;50(1):132-149. doi:10.1111/medu.12927

20. West CP, Huschka MM, Novotny PJ, et al. Association of perceived medical errors with resident distress and empathy: a prospective longitudinal study. JAMA. 2006;296(9):1071-1078.

21. Wallace JE, Lemaire JB, Ghali WA. Physician wellness: a missing quality indicator. Lancet. 2009;374(9702):1714-1721. doi:10.1016/ S0140-6736(09)61424-0

22. West CP, Tan AD, Habermann TM, Sloan JA, Shanafelt TD. Association of resident fatigue and distress with perceived medical errors. JAMA. 2009;302(12):1294-1300. doi:10.1001/jama.2009.1389

23. Shanafelt TD, Balch CM, Bechamps G, et al. Burnout and medical errors among American surgeons. Ann Surg. 2010;251(6):995-1000. doi:10.1097/SLA.0b013e3181bfdab3

24. Dyrbye LN, Shanafelt TD. Physician burnout: a potential threat to successful health care reform. JAMA. 2011;305(19):2009-2010. doi:10.1001/jama.2011.652

25. Shanafelt TD, Mungo M, Schmitgen J, et al. Longitudinal study evaluating the association between physician burnout and changes in professional work effort. Mayo Clinic Proc. 2016;91(4):422-431. doi:10.1016/j.mayocp.2016.02.001

26. Shanafelt TD, Balch CM, Dyrbye L, et al. Special report: suicidal ideation among American surgeons. Arch Surg. 2011;146(1):54-62. doi:10.1001/archsurg.2010.292

27. West CP, Tan AD, Shanafelt TD. Association of resident fatigue and distress with occupational blood and body fluid exposures and motor vehicle incidents. Mayo Clinic Proc. 2012;87(12):1138-1144. doi:10.1016/j.mayocp.2012.07.021

28. Hossain MM, Sultana A, Purohit N. Mental health outcomes of quarantine and isolation for infection prevention: a systematic umbrella review of the global evidence. SSRN Electronic Journal. 2020. doi:10.2139/ssrn.3561265

29. Sasangohar F, Jones S, Masud F, Vahidy FS, Kash BA. Provider burnout and fatigue during the COVID-19 pandemic: lessons learned from a high-volume intensive care unit. Anesth Analg. 2020;131 (1):106-111. doi:10.1213/ANE.0000000000004866

30. Freudenberger HJ. Staff burnout. J Soc Issues. 1974;30(1):159-165 doi:10.1111/j.1540-4560.1974.tb00706.x

31. Maslach C, Jackson SE. Maslach Burnout Inventory. 2nd ed. Palo Alto, CA: Consulting Psychologists Press; 1986.

32. Shimizu T, Mizoue T, Kubota S, Mishima N, Nagata S. Relationship between burnout and communication skill training among Japanese hospital nurses: a pilot study. J Occup Health. 2003;45(3):185-190. doi:10.1539/joh.45.185
33. Lambert EG, Kelley T, Hogan NL. Hanging on too long: the relationship between different forms of organizational commitment and emotional burnout among correctional staff. Am J Criminal Justice. 2013;38(1):51-66. doi:10.1007/s12103-012-9159-1

34. Maslach C, Jackson SE. The measurement of experienced burnout. J Organ Behav. 1981;2(2):99-113. doi:10.1002/job.4030020205

35. Ergin C. Doktor ve Hemşirelerde Tükenmişlik ve Maslach Tükenmişlik Ölçeğinin Uyarlanması. VII. Ulusal Psikoloji Kongresi Bilimsel Çalışmaları, Ankara. Türk Psikologlar Dernegi Yayinlari. 1993;143-154.

36. Karsavuran S. Sağlık Sektöründe Tükenmişlik: ankara'daki Sağlık Bakanlığı Hastaneleri Yöneticilerinin Tükenmişlik Düzeyleri. Hacettepe Üniv Iktisadi Ve Idari Bilimler Fakültesi Dergisi. 2014; 32(2):133-163.

37. Yildiz A, Çiçek İ, Şanli ME. Sağlık Çalışanlarında Tükenmişliğin Belirleyicileri: sigara ve Alkol Kullanımına Etkisinin İncelenmesi. Celal Bayar Üniv Saglik Bilimleri Enstitüsü Dergisi. 2018;5 (3):126-132.

38. Arık A, Turunç Ö. Tükenmişlik ve Örgütsel Bağlılık İlişkisinde Demografik Değişkenlerin Rolü: isparta Sağlık Çalışanlarında Bir Uygulama. Sosyal Bilimler Dergisi. 2016;3:109-130.

39. Sayıl I, Haran S, Ölmez Ş, Özgüven HD. Ankara Üniversitesi Hastanelerinde Çalışan Doktor ve Hemşirelerin Tükenmişlik Düzeyleri. Kriz Dergisi. 2011;5(2):71-77.

40. Arı GS, Bal EÇ. Tükenmişlik Kavramı: birey ve Örgütler Açısından Önemi. Yönetim Ve Ekonomi. 2008;15(1):131-148.

41. Helvacı I, Turhan M. Tükenmişlik Düzeylerinin İncelenmesi: silifke'de Görev Yapan Sağlık Çalışanları Üzerinde Bir Araştırma. Isletme Ve Iktisat Çalismalari Dergisi. 2013;1(4):58-68.

42. Can H, Güçlü YA, Doğan S, Erkaleli MB. Cerrahi ve Cerrahi Dışı Kliniklerdeki Asistan Hekimlerde Tükenmişlik Sendromu. Tepecil Egitim Hastanesi Dergisi. 2010;20(1):33-40.

43. Wu H, Liu L, Wang Y, Gao F, Zhao X, Wang L. Factors associated with burnout among Chinese hospital doctors: a cross-sectional study. BMC Public Health. 2013;13(1):786. doi:10.1186/14712458-13-786

44. Pu J, Zhou X, Zhu D, et al. Gender differences in psychological morbidity, burnout, job stress and job satisfaction among Chinese neurologists: a national cross-sectional study. Psychol Health Med. 2017;22(6):680-692. doi:10.1080/13548506.2016.1211717

45. Gunasingam N, Burns K, Edwards J, Dinh M, Walton M. Reducing stress and burnout in junior doctors: the impact of debriefing sessions. Postgrad Med J. 2015;91(1074):182-187. doi:10.1136/postgradmedj-2014-132847

46. Al-Dubai RS, Rampal K. Prevalence and associated factors of burnout among doctors in Yemen. J Occup Health. 2010;10:1539.

47. Ogundipe OA, Olagunju AT, Lasebikan VO, Coker AO. Burnout among doctors in residency training in a tertiary hospital. Asian J Psychiatr. 2014;10:27-32. doi:10.1016/j.ajp.2014.02.010

48. Saglik-Sen. Healthcare Professionals Socio-Demographic Determination and Burnout Survey, 2012.

49. Giusti EM, Pedroli E, D’Aniello GE, et al. The psychological impact of the COVID-19 outbreak on health professionals: a cross-sectional study. Front Psychol. 2020;11.

50. Azoulay E, De Waele J, Ferrer R, et al. Symptoms of burnout in intensive care unit specialists facing the COVID-19 outbreak. Ann Intensive Care. 2020;10(1):1-8. doi:10.1186/s13613-020-00722-3

51. Barello S, Palamenghi L, Graffigna G. Burnout and somatic symptoms among frontline healthcare professionals at the peak of the Italian COVID-19 pandemic. Psychiatry Res. 2020;290:113129. doi:10.1016/j.psychres.2020.113129

52. Wu Y, Wang J, Luo C, et al. A comparison of burnout frequency among oncology physicians and nurses working on the front lines and usual wards during the COVID-19 epidemic in Wuhan, China. J Pain Symptom Manage. 2020;60(1):60-65. doi:10.1016/j.jpainsymman.20 20.04.008 
53. Dimitriu MC, Pantea-Stoian A, Smaranda AC, et al. Burnout syndrome in Romanian medical residents in time of the COVID-19 pandemic. Med Hypotheses. 2020;144:109972. doi:10.1016/j.mehy. 2020.109972

54. Kannampallil TG, Goss CW, Evanoff BA, Strickland JR, McAlister RP, Duncan J. Exposure to COVID-19 patients increases physician trainee stress and burnout. PLoS One. 2020;15(8): e0237301. doi:10.1371/journal.pone.0237301

55. Colquitt J, Lepine JA, Wesson MJ. Organizational Behavior: Improving Performance and Commitment in the Workplace. New York, NY: McGraw-Hill Irwin; 2018.

56. Maslach C, Leiter MP. The Truth About Burnout: How Organizations Cause Personal Stress and What to Do About It. John Wiley \& Sons; 2008.

57. Shah K, Kamrai D, Mekala H, Mann B, Desai K, Patel RS. Focus on mental health during the coronavirus (COVID-19) pandemic: applying learnings from the past outbreaks. Cureus. 2020;12:3.
58. Patel RS, Bachu R, Adikey A, Malik M, Shah M. Factors related to physician burnout and its consequences: a review. Behav Sci (Basel). 2018;8(11):98. doi:10.3390/bs8110098

59. Regehr C, Glancy D, Pitts A, LeBlanc VR. Interventions to reduce the consequences of stress in physicians: a review and meta-analysis. J Nerv Ment Dis. 2014;202(5):353-359. doi:10.1097/NMD.000000 0000000130

60. West CP, Dyrbye LN, Erwin PJ, Shanafelt TD. Interventions to prevent and reduce physician burnout: a systematic review and meta-analysis. Lancet. 2016;388(10057):2272-2281. doi:10.1016/ S0140-6736(16)31279-X

61. Panagioti M, Panagopoulou E, Bower P, et al. Controlled interventions to reduce burnout in physicians: a systematic review and meta-analysis. JAMA Intern Med. 2017;177(2):195-205. doi:10.100 1/jamainternmed.2016.7674
Journal of Healthcare Leadership

\section{Publish your work in this journal}

The Journal of Healthcare Leadership is an international, peer-reviewed, open access journal focusing on leadership for the health profession. The journal is committed to the rapid publication of research focusing on but not limited to: Healthcare policy and law; Theoretical and practical aspects healthcare delivery; Interactions between healthcare and society and evidence-based practices; Interdisciplinary decision-making;
Dovepress

Philosophical and ethical issues; Hazard management; Research and opinion for health leadership; Leadership assessment. The manuscript management system is completely online and includes a very quick and fair peer-review system. Visit http://www.dovepress.com/ testimonials.php to read real quotes from published authors. 